\title{
Distinct origins of dura mater graft-associated Creutzfeldt-Jakob disease: past and future problems
}

\author{
Atsushi Kobayashi ${ }^{1}$, Yuichi Matsuura ${ }^{2}$, Shirou Mohri ${ }^{1}$ and Tetsuyuki Kitamoto ${ }^{{ }^{*}}$
}

\begin{abstract}
Dura mater graft-associated Creutzfeldt-Jakob disease (dCJD) can be divided into two subgroups that exhibit distinct clinical and neuropathological features, with the majority represented by a non-plaque-type of dCJD (np-dCJD) and the minority by a plaque-type of dCJD ( $p-d C J D$ ). The two distinct phenotypes of dCJD had been considered to be unrelated to the genotype (methionine, $\mathrm{M}$ or valine, $\mathrm{V}$ ) at polymorphic codon 129 of the PRNP gene or type (type 1 or type 2) of abnormal isoform of prion protein $\left(\mathrm{PrP}^{\mathrm{SC}}\right)$ in the brain, while these are major determinants of clinicopathological phenotypes of sporadic CJD (SCJD). The reason for the existence of two distinct subgroups in dCJD had remained elusive. Recent progress in research of the pathogenesis of $\mathrm{dCJD}$ has revealed that two distinct subgroups of $\mathrm{dCJD}$ are caused by infection with different $\operatorname{PrP}^{\mathrm{SC}}$ strains from sCJD, i.e., np-dCJD caused by infection with sCJD-MM1/MV1, and p-dCJD caused by infection with SCJD-W2 or -MV2. These studies have also revealed previously unrecognized problems as follows: (i) the numbers of p-dCJD patients may increase in the future, (ii) the potential risks of secondary infection from $d C J D$, particularly from p-dCJD, may be considerable, and (iii) the effectiveness of the current PrP ${ }^{S C}$ decontamination procedures against the $\mathrm{PrP}^{\mathrm{SC}}$ from $\mathrm{p}-\mathrm{dCJD}$ is uncertain. To prevent secondary infection from $\mathrm{p}-\mathrm{dCJD}$, the establishment of effective decontamination procedures is an urgent issue. In this review, we summarize the past and future problems surrounding dCJD.
\end{abstract}

Keywords: Creutzfeldt-Jakob disease, Prion protein, Dura mater grafts, Humanized knock-in mouse

\section{Introduction}

Dura mater grafts used to repair the dural defects at neurosurgery can cause fatal disease years to decades later. The tragedy of dura mater graft-associated Creutzfeldt-Jakob disease (dCJD) was considered to be nearly over. However, recent progress in research of the pathogenesis of dCJD has revealed previously unrecognized problems. In this review, we summarize the past and future problems surrounding dCJD.

Creutzfeldt-Jakob disease (CJD) is a lethal transmissible neurodegenerative disease. The central event in the pathogenesis of CJD is a conformational change of the normal cellular isoform of prion protein $\left(\operatorname{PrP}^{C}\right)$ into an abnormal infectious isoform of prion protein $\left(\mathrm{PrP}^{\mathrm{Sc}}\right)$ [1]. The conformational change of $\operatorname{PrP}^{\mathrm{C}}$ can occur due to

\footnotetext{
* Correspondence: kitamoto@med.tohoku.ac.jp

'Department of Neurological Science, Tohoku University Graduate School of Medicine, 2-1 Seiryo-machi, Aoba-ku, Sendai 980-8575, Japan

Full list of author information is available at the end of the article
}

either one of three causes: spontaneous conversion in sporadic CJD (sCJD), mutations in the PRNP gene in genetic CJD, or infection with $\operatorname{PrP}^{\mathrm{Sc}}$ in iatrogenic CJD and variant CJD.

One of the most frequent sources of iatrogenic $\operatorname{PrP}^{\mathrm{Sc}}$ infection is dura mater grafts obtained from human cadavers undiagnosed as CJD. The sum of dCJD (228 cases) and growth hormone-associated CJD (226 cases) accounts for $97 \%$ of total iatrogenic CJD cases [2]. A single brand of dura mater graft, Lyodura ${ }^{\circ}$, was used for all the dCJD cases in whom the brand name was identified. Although the causative dura mater grafts were manufactured by a German company, 62\% (142 cases) of total dCJD cases have been found in Japan [2,3]. Persistent efforts of a Japanese CJD surveillance team have clarified the outline of dCJD outbreaks. The onset of Japanese dCJD patients peaked in the late 1990s, and most of the patients had received the grafts during 1983-1987, while as many as 100,000 persons received the Lyodura ${ }^{\circ}$ grafts 


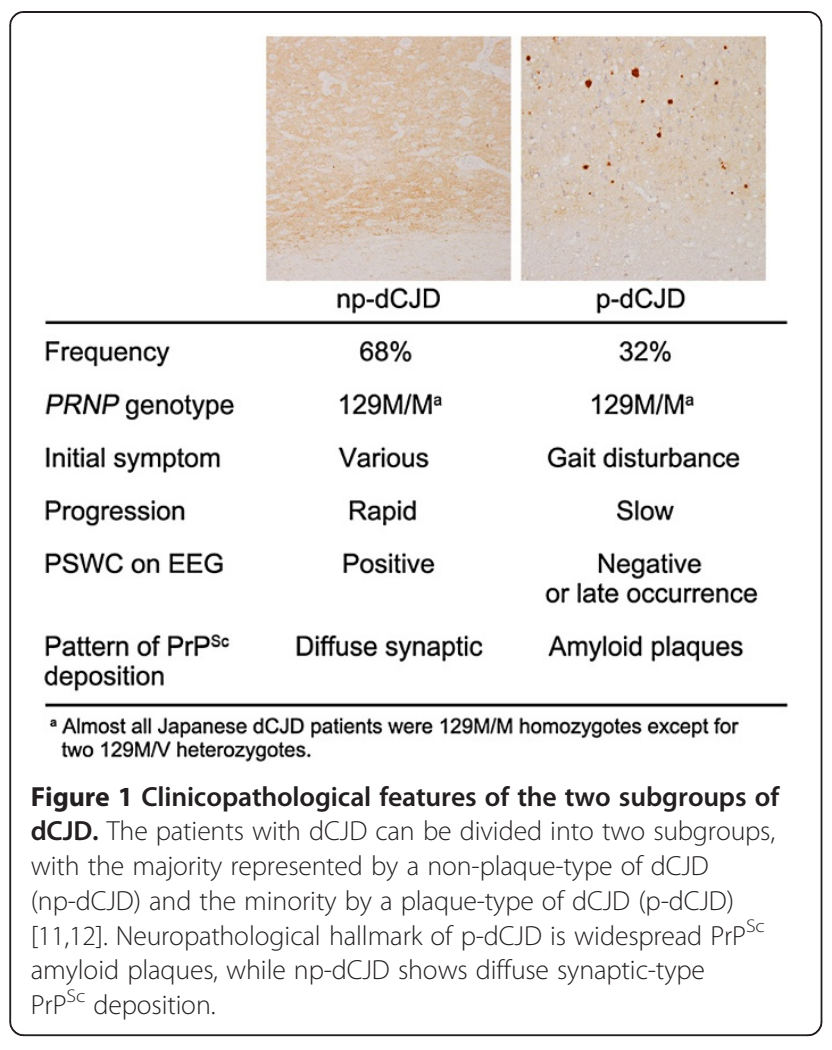

during this period $[4,5]$. In the process of conducting this elaborate survey, a puzzling mystery about dCJD emerged.

\section{A mystery about dCJD}

There is growing evidence that $\mathrm{dCJD}$ can be divided into two subgroups that exhibit distinct clinical and neuropathological phenotypes, with the majority (68\%) represented by a non-plaque-type of dCJD (np-dCJD) and the minority (32\%) by a plaque-type of dCJD (p-dCJD) (Figure 1) [6-12]. The clinicopathological features of
np-dCJD are identical to those of classical sCJD, whereas $\mathrm{p}$-dCJD is characterized by (i) ataxic gait as an initial symptom, (ii) slow progression of neurological symptoms, (iii) absence or late occurrence of periodic sharp-wave complexes (PSWC) on electroencephalogram (EEG), and (iv) widespread $\operatorname{PrP}^{\mathrm{Sc}}$ amyloid plaques in the brain [11-16]. There is no significant difference in gender composition, site of graft, age at grafting, and year of grafting between the two subgroups $[11,12]$.

sCJD also shows wide phenotypic heterogeneity, and its clinicopathological phenotypes are determined by the genotype at polymorphic codon 129 of the PRNP gene and type of $\operatorname{PrP}^{\mathrm{Sc}}$ in the brain (Figure 2) $[17,18]$. The codon 129 of the PRNP gene shows methionine $(\mathrm{M}) / \mathrm{val}-$ ine $(\mathrm{V})$ polymorphism. Two types of $\operatorname{PrP}^{\mathrm{Sc}}$ (type 1 and type 2) are distinguishable according to the size of the proteinase K-resistant core of unglycosylated $\operatorname{Pr} \mathrm{P}^{\mathrm{Sc}}$ (21 and $19 \mathrm{kDa}$, respectively), reflecting differences in the proteinase K-cleavage site (at residues 82 and 97, respectively) [19]. On the other hand, the two distinct phenotypes of dCJD had been considered to be unrelated to their PRNP genotype or type of $\operatorname{PrP}^{\mathrm{Sc}}$ in the brain [11]. In Japan, almost all dCJD patients had the same genotype, i.e., homozygous for methionine at codon 129 (129 M/M), except two heterozygotes [2], and the type of $\mathrm{PrP}^{\mathrm{Sc}}$ in their brains had been reported as type 1 $[6,10,11]$. The reason for the existence of two distinct subgroups in dCJD had remained elusive.

\section{Solving the mystery}

In 2003, an unusual p-dCJD case was reported [9]. This patient showed the accumulation of unusual $\mathrm{PrP}^{\mathrm{Sc}}$ with intermediate electrophoretic mobility between types 1 and $2 \operatorname{PrP}^{\mathrm{Sc}}$. Then, we reevaluated the biochemical properties of $\operatorname{PrP}^{\mathrm{Sc}}$ in the two subgroups of $\mathrm{dCJD}$ and found that the size of $\operatorname{PrP}^{\mathrm{Sc}}$ from $\mathrm{p}-\mathrm{dCJD}$ was invariably smaller than that of type $1 \operatorname{PrP}^{\mathrm{Sc}}$ from np-dCJD

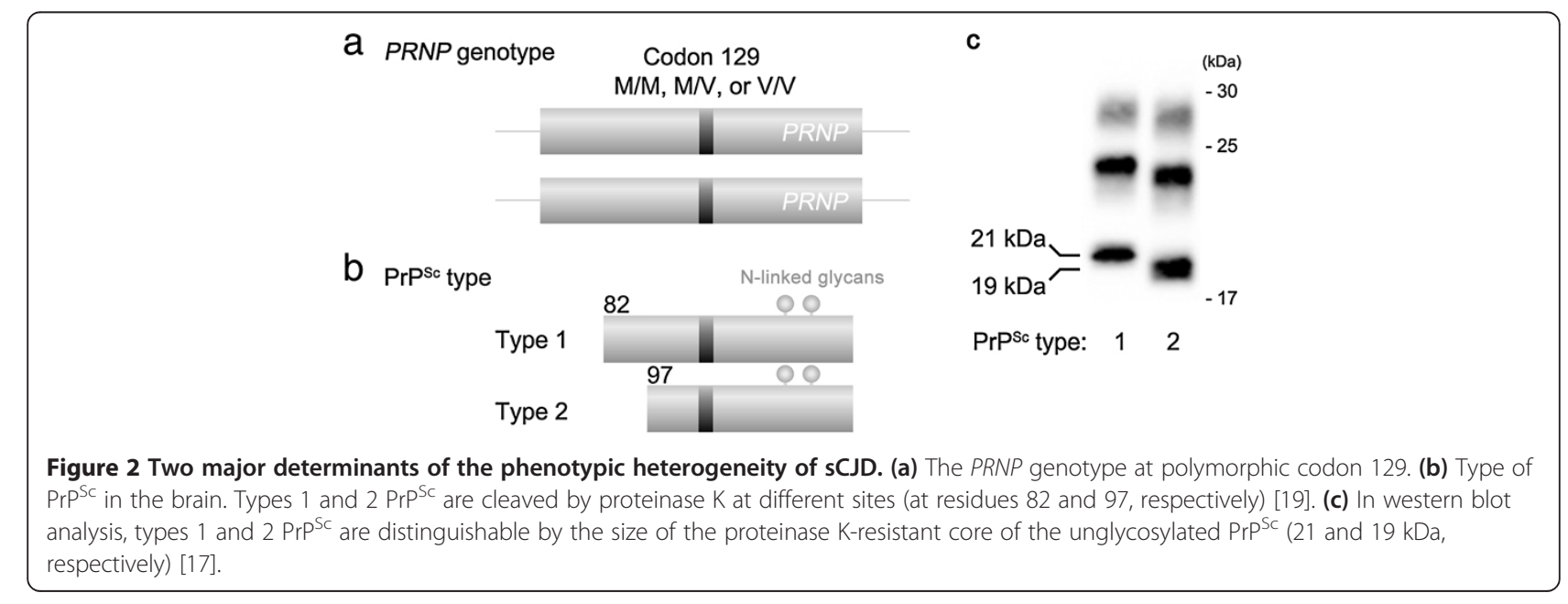




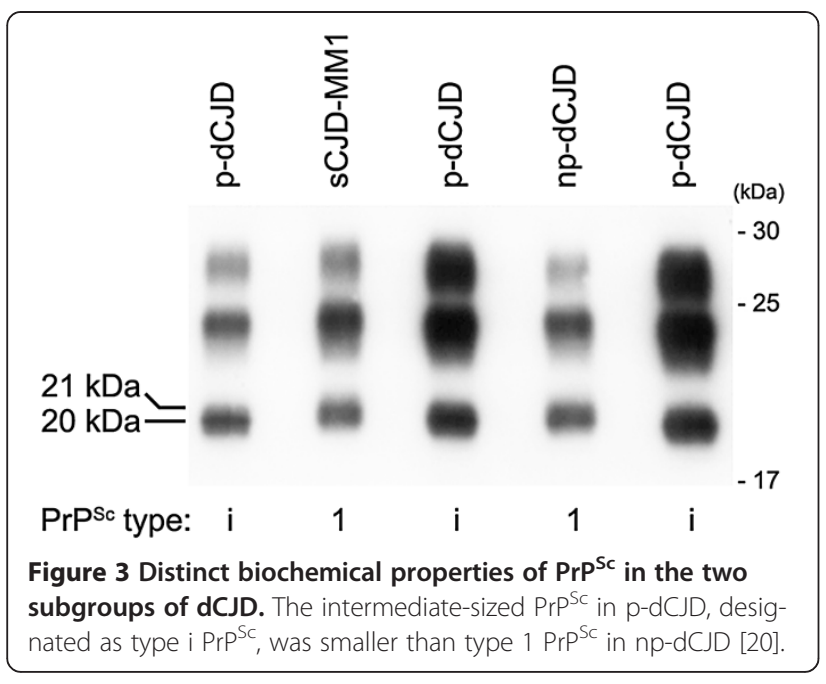

(Figure 3) [20]. This intermediate-sized $\operatorname{PrP}^{\mathrm{Sc}}$ was designated as type i $\operatorname{PrP}^{\mathrm{Sc}}$.

To resolve the mystery of the existence of two distinct subgroups in $\mathrm{dCJD}$, we hypothesized that they might be caused by infection with different $\operatorname{PrP}^{\mathrm{Sc}}$ strains from distinct sCJD subgroups. According to the PRNP genotype and type of $\mathrm{PrP}^{\mathrm{Sc}}$ in the brain, sCJD is classified into six subgroups (MM1, MV1, VV1, MM2, MV2, or VV2) [17]. MM1 and MV1, which are the predominant subgroups in SCJD, show the same clinicopathological features. Meanwhile, MM2 can be divided into three subgroups based on histopathological criteria (MM2T, thalamic form showing characteristic atrophy of thalamic and inferior olivary nuclei; MM2C, cortical form showing a predominant cortical pathology; or MM2T + $\mathrm{C}$, mixed form) $[17,21]$. In addition, MV2 is also divided into three subgroups based on histopathological criteria (MV2K showing kuru type $\operatorname{PrP}^{\mathrm{Sc}}$ amyloid plaques, MV2C showing a predominant cortical pathology, or MV2K + C showing mixed histopathology) $[17,18]$. The clinicopathological features of np-dCJD, such as short duration of illness, PSWC on EEG, or diffuse synaptic-type $\mathrm{PrP}^{\mathrm{Sc}}$ deposition in the brain, are identical to those of sCJD-MM1/MV1. In contrast, the clinicopathological features of p-dCJD, such as ataxic gait as an initial symptom, slow progression of neurological symptoms, absence or late occurrence of PSWC on EEG, or formation of $\mathrm{PrP}^{\mathrm{Sc}}$ plaques in the brain, are similar to those of sCJD-VV2, $-\mathrm{MV} 2 \mathrm{~K}$, or $-\mathrm{MV} 2 \mathrm{~K}+\mathrm{C}$. These similarities raised the possibility that np-dCJD might be caused by infection with sCJD-MM1/MV1, whereas p-dCJD might be caused by infection with sCJD-VV2, $-\mathrm{MV} 2 \mathrm{~K}$, or -MV2K + C.

To test this possibility, we examined the transmission properties of the dCJD and SCJD subgroups using humanized mice carrying human PrP with either the $129 \mathrm{M} / \mathrm{M}$ or $\mathrm{V} / \mathrm{V}$ genotype $[20,22,23]$. In these transmission experiments, $\mathrm{p}$-dCJD and sCJD-VV2, -MV2K, or $-\mathrm{MV} 2 \mathrm{~K}+\mathrm{C}$ were identical in the transmissibility to the PrP-humanized mice (Table 1, Figure 4a) and in the neuropathological and biochemical features in the inoculated mice (Figure 4b, c). By contrast, np-dCJD showed the same transmission properties as SCJD-MM1. In particular, the $129 \mathrm{M} / \mathrm{M}$ mice inoculated with sCJDVV2, $-\mathrm{MV} 2 \mathrm{~K}$, or $-\mathrm{MV} 2 \mathrm{~K}+\mathrm{C}$ material showed widespread $\mathrm{PrP}^{\mathrm{Sc}}$ plaques and type $\mathrm{i} \mathrm{PrP}^{\mathrm{Sc}}$ accumulation similar to the p-dCJD patients, whereas the $129 \mathrm{M} / \mathrm{M}$ mice inoculated with sCJD-MM1 material showed diffuse synaptic-type $\operatorname{PrP}^{\mathrm{Sc}}$ deposition and type $1 \operatorname{PrP}^{\mathrm{Sc}}$ accumulation similar to the np-dCJD patients. Thus, these animal models support the hypothesis that the origin of np-dCJD is sCJD-MM1/MV1 and that of p-dCJD is

Table 1 Transmission of dCJD or sCJD to PrP-humanized mice

\begin{tabular}{|c|c|c|c|}
\hline \multirow[t]{4}{*}{ Inoculum (ID) } & \multicolumn{3}{|c|}{ Incubation period in days $\pm \operatorname{SEM}\left(n / n^{0}\right)^{a}$} \\
\hline & \multicolumn{2}{|c|}{$129 \mathrm{M} / \mathrm{M}$} & \multirow{3}{*}{$\frac{129 \mathrm{~V} / \mathrm{V}}{\mathrm{Ki}-\mathrm{Hu} 129 \mathrm{~V} / \mathrm{V}^{\mathrm{b}}}=$} \\
\hline & $\mathrm{Tg}+\mathrm{Ki}-\mathrm{Hu} 129 \mathrm{M} / \mathrm{M}^{\mathrm{b}}$ & Ki-Hu129M/M ${ }^{b}$ & \\
\hline & $(9.8 x)^{c}$ & $(1 \times)$ & \\
\hline np-dCJD (GF) & $161 \pm 5(5 / 5)$ & N.D. ${ }^{d}$ & N.D. \\
\hline$n p-d C J D(T C)$ & $208 \pm 2(5 / 5)$ & N.D. & N.D. \\
\hline$p-d C J D(K R)$ & $420 \pm 10(5 / 5)$ & $685 \pm 51(5 / 5)$ & $259 \pm 6(6 / 6)$ \\
\hline $\mathrm{p}-\mathrm{dCJD}(\mathrm{KD})$ & $398 \pm 10(5 / 5)$ & $447 \pm 51(6 / 6)$ & $317 \pm 8(11 / 11)$ \\
\hline sCJD-MM1 & $175 \pm 4(9 / 9)$ & $467 \pm 24(8 / 8)$ & $774 \pm 32(6 / 6)$ \\
\hline sCJD-W2 & $505 \pm 14(5 / 5)$ & $633 \pm 49(6 / 6)$ & $302 \pm 9(7 / 7)$ \\
\hline sCJD-MV2K & N.D. & $638 \pm 57(4 / 4)$ & $329 \pm 3(4 / 4)$ \\
\hline sCJD-MV2K+C & N.D. & $600 \pm 22(6 / 6)$ & $332 \pm 15(4 / 4)$ \\
\hline 129 M/M mouse-passaged sCJD-W2 & N.D. & $685 \pm 17(6 / 6)$ & $309 \pm 3(7 / 7)$ \\
\hline
\end{tabular}

${ }^{a} n$, number of mice positive for PrP accumulation in the immunohistochemical analysis; $n^{0}$, number of inoculated mice.

$\mathrm{Ki}-\mathrm{Hu} 129 \mathrm{M} / \mathrm{M}$, knock-in mice expressing human PrP with the $129 \mathrm{M} / \mathrm{M}$ genotype; Ki-Hu129V/V, knock-in mice expressing human PrP with the $129 \mathrm{~V} / \mathrm{V}$ genotype; $\mathrm{Tg}+\mathrm{Ki}-\mathrm{Hu} 129 \mathrm{M} / \mathrm{M}$, Ki-Hu129M/M crossed with transgenic mice overexpressing human PrP with the $129 \mathrm{M}$ genotype.

${ }^{\mathrm{d}}$ N.D., not done. 


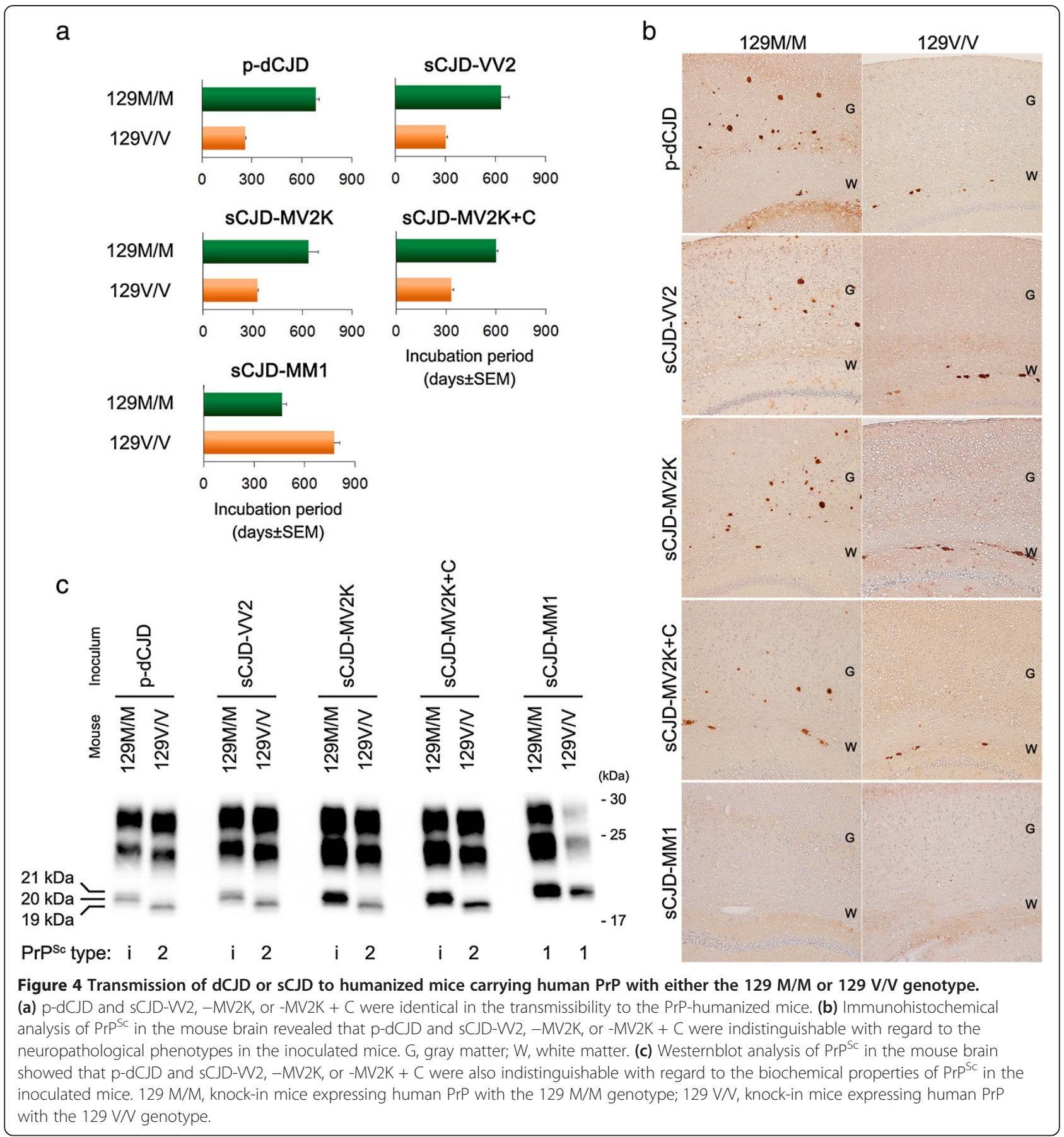

sCJD-VV2, $-\mathrm{MV} 2 \mathrm{~K}$, or -MV2K + C. Indeed, the incidence rate of p-dCJD (32\%) among total dCJD is close to the sum total of the incidence of sCJD-VV2 (15\%), -MV2K (8\%), and -MV2K + C (3\%) [18].

\section{Molecular basis of the generation of two distinct} subgroups in dCJD

At the molecular level, np-dCJD contains type $1 \operatorname{PrP}^{\mathrm{Sc}}$ with the codon $129 \mathrm{M}$ genotype (denoted as M1 $\operatorname{PrP}^{\mathrm{Sc}}$ ), whereas $\mathrm{p}$-dCJD contains type $\mathrm{i} \mathrm{PrP}^{\mathrm{Sc}}$ with the codon $129 \mathrm{M}$ genotype $\left(\mathrm{Mi} \mathrm{PrP}{ }^{\mathrm{Sc}}\right.$ ) (Table 2). Meanwhile, sCJDMM1/MV1 contains M1 PrP ${ }^{\mathrm{Sc}}$, and sCJD-VV2 contains type $2 \mathrm{PrP}^{\mathrm{Sc}}$ with the codon $129 \mathrm{~V}$ genotype (V2 $\mathrm{PrP}^{\mathrm{Sc}}$ ). Recently, we found that $\mathrm{SCJD}-\mathrm{MV} 2 \mathrm{~K}$ contains $\mathrm{Mi} \mathrm{PrP}^{\mathrm{Sc}}$ and V2 $\mathrm{PrP}^{\mathrm{Sc}}$, whereas sCJD-MV2K $+\mathrm{C}$ also contains type $2 \mathrm{PrP}^{\mathrm{Sc}}$ with the codon $129 \mathrm{M}$ genotype and cortical pathology (M2C $\left.\operatorname{PrP}^{\mathrm{Sc}}\right)$ in addition to Mi $\operatorname{PrP}^{\mathrm{Sc}}$ and V2 $\mathrm{PrP}^{\mathrm{Sc}}$ (Table 2) [23]. M2 $\mathrm{PrP}^{\mathrm{Sc}}$ can be divided into 
Table 2 Molecular classification of dCJD and sCJD

\begin{tabular}{|c|c|c|c|c|c|}
\hline Classification $^{\mathrm{a}}$ & Codon 129 genotype & PrPsc type & Transmission type $^{\mathbf{b}}$ & Original $\mathrm{PrP}^{\mathrm{Sc}}$ & Existing PrP ${ }^{\mathrm{Sc}}$ \\
\hline$\overline{n p-d C J D}$ & $\mathrm{M} / \mathrm{M}$ & 1 & M1 & M1 & M1 \\
\hline$p-d C J D$ & $\mathrm{M} / \mathrm{M}$ & $i^{c}$ & V2 & $V 2^{d}$ & $\mathrm{Mi}$ \\
\hline sCJD-MM1 & $\mathrm{M} / \mathrm{M}$ & 1 & M1 & M1 & M1 \\
\hline sCJD-W2 & VN & 2 & V2 & V2 & V2 \\
\hline sCJD-MV2K & $\mathrm{MN}$ & $i+2$ & V2 & V2 & $\mathrm{Mi}+\mathrm{V} 2$ \\
\hline sCJD-MV2K+C & MN & $i+2$ & V2 & $\mathrm{M} 2 \mathrm{C}^{\mathrm{e}}+\mathrm{V} 2$ & $\mathrm{M} 2 \mathrm{C}+\mathrm{Mi}+\mathrm{V} 2$ \\
\hline
\end{tabular}

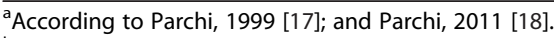

${ }^{b}$ According to Bishop, 2010 [24]; Kobayashi, 2007 [20]; and Kobayashi, 2013 [23].

Intermediate type located between types 1 and $2 \mathrm{PrP}^{\mathrm{Sc}}$.

${ }^{\mathrm{d}}$ Although not only V2 $\mathrm{PrP}^{\mathrm{SC}}$ but also Mi PrP ${ }^{\mathrm{SC}}$ can cause $\mathrm{p}-\mathrm{dCJD}$ if transmitted to the $129 \mathrm{M} / \mathrm{M}$ individuals, the primary origin of Mi PrP ${ }^{\mathrm{Sc}}$ is V2 PrP ${ }^{\mathrm{Sc}}$ (see text).

${ }^{\mathrm{e}} \mathrm{M} 2 \mathrm{PrP}^{\mathrm{Sc}}$ can be divided into two subgroups based on histopathological phenotypes. M2C PrP ${ }^{\mathrm{Sc}}$ causes a predominant cortical pathology, whereas M2T PrP ${ }^{\mathrm{Sc}}$ causes atrophy of thalamic and inferior olivery nuclei.

two subgroups based on histopathological phenotypes. $\mathrm{M} 2 \mathrm{C} \operatorname{PrP}^{\mathrm{Sc}}$ causes a predominant cortical pathology in sCJD-MM2C, $-\mathrm{MV} 2 \mathrm{C}$, or -MV2K + C, whereas M2T $\operatorname{PrP}^{\mathrm{Sc}}$ causes atrophy of thalamic and inferior olivery nuclei in SCJD-MM2T.

The generation of $\mathrm{M} 1 \mathrm{PrP}^{\mathrm{Sc}}$ in np-dCJD is simply due to the infection with $\mathrm{M} 1 \mathrm{PrP}^{\mathrm{Sc}}$ from sCJD-MM1/MV1. On the other hand, the generation of $\mathrm{Mi} \operatorname{PrP}^{\mathrm{Sc}}$ in $\mathrm{p}$-dCJD is rather complicated. Transmission of $\mathrm{V} 2 \mathrm{PrP}^{\mathrm{Sc}}$, i.e., sCJD-VV2, to the $129 \mathrm{M} / \mathrm{M}$ mice generated $\mathrm{Mi}$ $\mathrm{PrP}^{\mathrm{Sc}}$ (Figure 4c) [20]. Similarly, transmission of $\mathrm{Mi}$ $\mathrm{PrP}^{\mathrm{Sc}}$, i.e., $\mathrm{p}-\mathrm{dCJD}$, to the $129 \mathrm{M} / \mathrm{M}$ mice also generated Mi PrP $P^{\mathrm{Sc}}$. Therefore, both $\mathrm{V} 2 \operatorname{PrP}^{\mathrm{Sc}}$ and Mi PrP ${ }^{\mathrm{Sc}}$ can generate $\mathrm{Mi} \mathrm{PrP}^{\mathrm{Sc}}$ if transmitted to individuals with the $129 \mathrm{M} / \mathrm{M}$ genotype. Indeed, transmission of sCJDMV2K containing Mi PrP ${ }^{\mathrm{Sc}}$ and V2 $\mathrm{PrP}^{\mathrm{Sc}}$ to the $129 \mathrm{M} /$ $\mathrm{M}$ mice also generated Mi $\operatorname{PrP}^{\mathrm{Sc}}$ (Figure 4c). Meanwhile, sCJD-MV2K + C contains M2C PrP ${ }^{\mathrm{Sc}}$ besides Mi PrP $\mathrm{P}^{\mathrm{Sc}}$ and $\mathrm{V} 2 \mathrm{PrP}^{\mathrm{Sc}}$ (Table 2). However, $\mathrm{M} 2 \mathrm{C} \mathrm{PrP}^{\mathrm{Sc}}$ lacks or has very low infectivity and does not affect the transmission properties of the coexisting $\mathrm{PrP}^{\mathrm{Sc}}$ [23]. Therefore, the transmission of sCJD-MV2K + C to the $129 \mathrm{M} / \mathrm{M}$ mice can also result in the generation of $\mathrm{Mi} \mathrm{PrP}^{\mathrm{Sc}}$ (Figure 4c). Taken together, $\mathrm{Mi} \mathrm{PrP}{ }^{\mathrm{Sc}}$ in $\mathrm{p}$-dCJD is generated by infection with $\mathrm{Mi} \mathrm{PrP}^{\mathrm{Sc}}$ and/or $\mathrm{V} 2 \mathrm{PrP}^{\mathrm{Sc}}$ from sCJD-VV2, $-\mathrm{MV} 2 \mathrm{~K}$, or $-\mathrm{MV} 2 \mathrm{~K}+\mathrm{C}$. It is noteworthy that Mi $\operatorname{PrP}^{\mathrm{Sc}}$ can be observed in the $129 \mathrm{M} / \mathrm{M}$ mice inoculated with V2 $\mathrm{PrP}^{\mathrm{Sc}}$ but not in SCJD patients with the $129 \mathrm{M} / \mathrm{M}$ genotype, suggesting that $\mathrm{Mi} \operatorname{PrP}^{\mathrm{Sc}}$ in sCJD$\mathrm{MV} 2 \mathrm{~K}$ or $-\mathrm{MV} 2 \mathrm{~K}+\mathrm{C}$ is also generated by V2 $\mathrm{PrP}^{\mathrm{Sc}}$ seed-dependent conversion but not by spontaneous conversion of the $129 \mathrm{M} \mathrm{PrP}^{\mathrm{C}}$. Therefore, the primary origin of Mi PrP $\mathrm{P}^{\mathrm{Sc}}$ is $\mathrm{V} 2 \mathrm{PrP}^{\mathrm{Sc}}$. This can account for the similarities in transmission properties between $\mathrm{Mi} \operatorname{PrP}^{\mathrm{Sc}}$ and V2 $\operatorname{PrP}^{\mathrm{Sc}}$. Thus, M1 $\operatorname{PrP}^{\mathrm{Sc}}$ in $\mathrm{np}-\mathrm{dCJD}$ and $\mathrm{Mi} \operatorname{PrP}^{\mathrm{Sc}}$ in p-dCJD are completely different with regard to the neuropathological phenotypes, biochemical features, and transmission properties, reflecting their distinct $\operatorname{PrP}^{\mathrm{Sc}}$ origins. In contrast to $\mathrm{M} 1 \mathrm{PrP}^{\mathrm{Sc}}$, which is the most common $\operatorname{PrP}^{\mathrm{Sc}}$ observed in SCJD patients with the $129 \mathrm{M} / \mathrm{M}$ genotype, Mi $\mathrm{PrP}^{\mathrm{Sc}}$ has never been observed in SCJD patients with the $129 \mathrm{M} / \mathrm{M}$ genotype. Therefore, the detection of $\mathrm{Mi} \mathrm{PrP}^{\mathrm{Sc}}$ can be sound evidence of iatrogenic infection in individuals with the $129 \mathrm{M} / \mathrm{M}$ genotype and would contribute to reliable surveillance of iatrogenic cases such as p-dCJD.

To verify experimentally that $\mathrm{Mi} \operatorname{PrP}^{\mathrm{Sc}}$ originates from $\mathrm{V} 2 \mathrm{PrP}^{\mathrm{Sc}}$ and its transmission properties are identical to those of the parental V2 $\mathrm{PrP}^{\mathrm{Sc}}$, we performed a modeling study using PrP-humanized mice (Figure 5a) [25]. As described above, the $129 \mathrm{M} / \mathrm{M}$ mice inoculated with $\mathrm{V} 2 \mathrm{PrP}^{\mathrm{Sc}}$ showed widespread $\operatorname{PrP}^{\mathrm{Sc}}$ plaques and Mi $\operatorname{PrP}^{\mathrm{Sc}}$ accumulation in the brain as an experimental model of $\mathrm{p}$-dCJD. We then inoculated the Mi PrP $\mathrm{P}^{\mathrm{Sc}}$ from these mice into other PrP-humanized mice with either the $129 \mathrm{M} / \mathrm{M}$ or V/V genotype. This secondary passage revealed that the transmission properties of the $\mathrm{Mi} \operatorname{PrP}^{\mathrm{Sc}}$, i.e., $129 \mathrm{M} / \mathrm{M}$ mouse-passaged SCJD-VV2, are identical to those of the parental V2 $\mathrm{PrP}^{\mathrm{Sc}}$. In particular, although the incompatibility of the codon 129 genotypes between host and inoculum usually results in a prolonged incubation period [20], the $129 \mathrm{~V} / \mathrm{V}$ mice inoculated with the Mi $\operatorname{PrP}^{\mathrm{Sc}}$ showed a shorter incubation period compared with the $129 \mathrm{M} / \mathrm{M}$ mice (Table 1). Moreover, the altered neuropathological phenotype and biochemical properties at the primary passage in the $129 \mathrm{M} / \mathrm{M}$ mice reverted to the original ones in the secondary passage in the $129 \mathrm{~V} / \mathrm{V}$ mice (Figure 5b, c). Thus, this modeling study shows that (i) V2 $\mathrm{PrP}^{\mathrm{Sc}}$ infection in a host with the incompatible codon $129 \mathrm{M} / \mathrm{M}$ genotype generates an unusual $\operatorname{PrP}^{\mathrm{Sc}}$ with altered conformational properties, i.e., $\mathrm{Mi} \mathrm{PrP}^{\mathrm{Sc}}$, (ii) the emerging Mi $\mathrm{PrP}^{\mathrm{Sc}}$ retains the memory of the parental V2 $\mathrm{PrP}^{\mathrm{Sc}}$ within its conformational properties, and (iii) the parental $\mathrm{V} 2 \mathrm{PrP}^{\mathrm{Sc}}$ re-emerges and proliferates rapidly if the $\mathrm{Mi}$ $\mathrm{PrP}^{\mathrm{Sc}}$ is transmitted to the original host with the codon $129 \mathrm{~V} / \mathrm{V}$ genotype. This phenomenon, designated as traceback, can be a useful tool to identify the origin of $\operatorname{PrP}^{\mathrm{Sc}}$ infection if atypical $\operatorname{PrP}^{\mathrm{Sc}}$ emerges in the future $[20,22,26]$. 


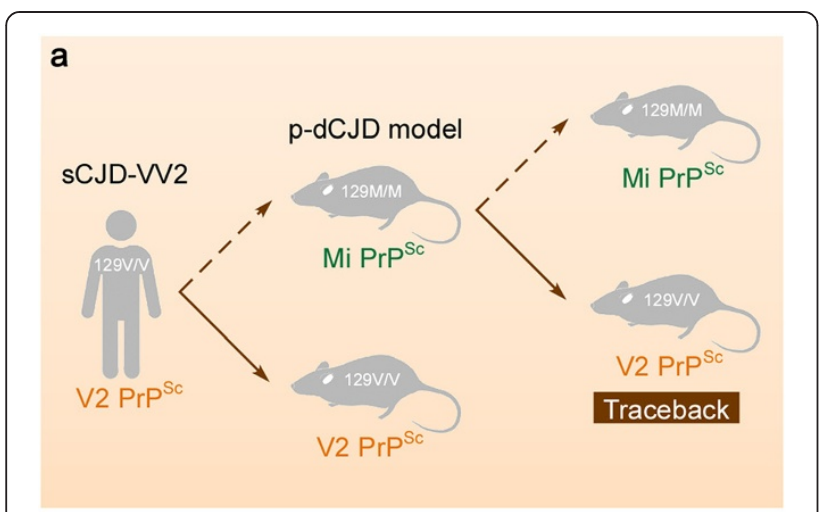

b

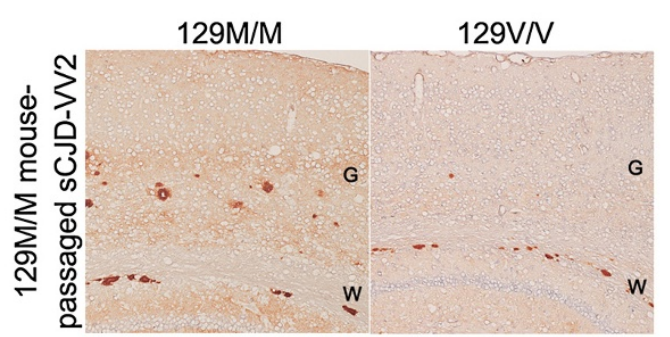

C

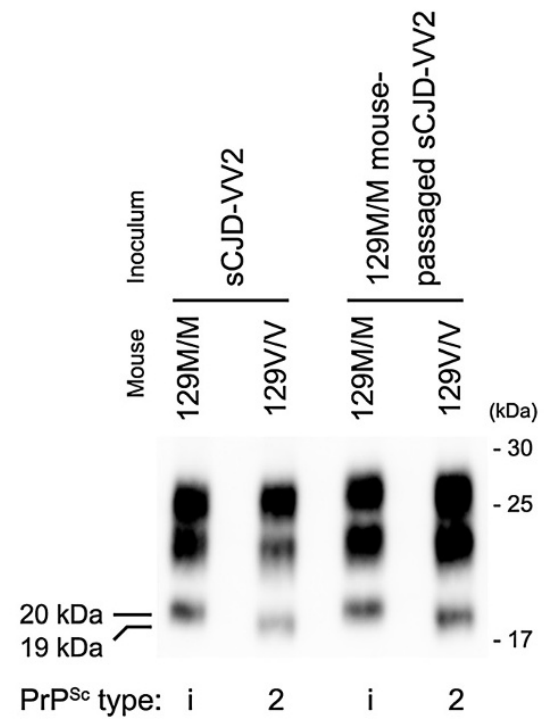

Figure 5 Modeling of p-dCJD and traceback phenomenon. (a) Schematic diagram of the modeling study. The $129 \mathrm{~V} /$ mice were highly susceptible to the 129 M/M mouse-passaged sCJD-W2, i.e., Mi PrP ${ }^{\mathrm{SC}}$, despite their incompatible codon 129 genotypes. Moreover, the altered neuropathological and biochemical phenotypes in the primary passage in the $129 \mathrm{M} / \mathrm{M}$ mice reverted to the original ones in the secondary passage in the $129 \mathrm{~V} / \mathrm{N}$ mice. This is because the origin of Mi PrPSC is V2 $\mathrm{PrP}^{\mathrm{Sc}}$. This phenomenon has been designated as traceback $[20,26]$. (b) Immunohistochemical analysis of PrP ${ }^{S c}$ in the brains from the PrP-humanized mice infected with the 129 M/M mouse-passaged SCJD-W2. G, gray matter; W, white matter. (c) Westernblot analysis of $\operatorname{PrP}^{\mathrm{Sc}}$ in the brains from the PrP-humanized mice infected with SCJD-W2 or the $129 \mathrm{M} / \mathrm{M}$ mouse-passaged sCJD-WV2. 129 M/M, knock-in mice expressing human PrP with the 129 M/M genotype; 129 VN, knock-in mice expressing human PrP with the 129 VN genotype.

\section{Remaining problems}

Our transmission studies resolved the complicated pathogenesis of dCJD. However, they have also revealed several issues surrounding $\mathrm{dCJD}$ that need to be addressed in the future.

First, the numbers of p-dCJD patients may increase in the future. The experimental p-dCJD model, i.e., the $129 \mathrm{M} / \mathrm{M}$ mice inoculated with $\mathrm{Mi} \mathrm{PrP}^{\mathrm{Sc}}$ and/or V2 $\mathrm{PrP}^{\mathrm{Sc}}$ from sCJD-VV2, -MV2K, or -MV2K + C, showed a longer incubation period compared with the np-dCJD model, i.e., the $129 \mathrm{M} / \mathrm{M}$ mice inoculated with $\mathrm{M} 1 \mathrm{PrP}^{\mathrm{Sc}}$ from SCJD-MM1 (Table 1). This raises the concern that additional $\mathrm{p}$-dCJD patients, who are presenting still at the subclinical stage, may emerge after a longer incubation period in the future. Although the numbers of patients with newly developed dCJD have dropped off, continuous surveillance will be required to find remaining $\mathrm{p}$-dCJD cases.

Second, the potential risks of secondary infection from $\mathrm{dCJD}$, particularly from $\mathrm{p}-\mathrm{dCJD}$, may be considerable. As described above, the transmission studies raise a concern about the existence of subclinical p-dCJD patients. dCJD patients may undergo more than one neurosurgical operation due to their underlying diseases (the primary disease for which the neurosurgery was performed) [4]. In addition, p-dCJD patients may be more frequently autopsied because the clinical features of p-dCJD are atypical compared with those of classical sCJD [11]. These facts suggest that there may be considerable risk of secondary infection from $\mathrm{p}$-dCJD patients. Individuals with the $129 \mathrm{~V} / \mathrm{V}$ genotype may be more vulnerable to the infection with Mi $\mathrm{PrP}^{\mathrm{Sc}}$ from $\mathrm{p}-\mathrm{dCJD}$, as suggested by the fact that the $129 \mathrm{~V} / \mathrm{V}$ mice were highly susceptible to $\mathrm{Mi} \mathrm{PrP}^{\mathrm{Sc}}$ in the transmission study (Table 1). Additionally, $129 \mathrm{M} / \mathrm{M}$ individuals may be also affected after a prolonged incubation period, as suggested by the high attack rate $(100 \%)$ of the $129 \mathrm{M} / \mathrm{M}$ mice inoculated with $\mathrm{Mi} \mathrm{PrP}^{\mathrm{Sc}}$. Therefore, secondary infection from p-dCJD can occur regardless of the codon 129 genotype. Comprehensive analysis of the distribution of $\operatorname{PrP}^{\mathrm{Sc}}$ in the peripheral tissues of $\mathrm{p}$-dCJD patients will be also required to assess the potential risks of secondary infection.

Finally, the efficacy of the current $\operatorname{PrP}^{\mathrm{Sc}}$ decontamination procedures against $\mathrm{Mi} \operatorname{PrP}^{\mathrm{Sc}}$ needs to be tested in the future. Mi $\operatorname{PrP}^{\mathrm{Sc}}$ in $\mathrm{p}-\mathrm{dCJD}$ and $\mathrm{M} 1 \mathrm{PrP}^{\mathrm{Sc}}$ in npdCJD differ in the sizes of the proteinase K-resistant core, suggesting their conformational differences. Moreover, their parental $\operatorname{PrP}^{\mathrm{Sc}}$ strains are also different. Different $\operatorname{PrP}^{\mathrm{Sc}}$ strains can show different thermostability $[27,28]$ and different susceptibility to the decontamination procedures [29]. To prevent the spread of secondary infection from dCJD patients to medical workers or other patients, adequate decontamination and disinfection of 
the instruments used for neurosurgery or autopsy are essential. However, the current $\operatorname{PrP}^{\mathrm{Sc}}$ decontamination procedures were developed using scrapie isolates and tested using CJD isolates other than p-dCJD [30-32]. Therefore, further studies using $\mathrm{Mi} \operatorname{PrP}^{\mathrm{Sc}}$ will be needed to assess the effectiveness of the current procedures. For this purpose, sensitive detection systems for $\mathrm{Mi} \operatorname{PrP}^{\mathrm{Sc}}$ are also prerequisite to evaluating quantitatively the reduction of infectivity after the decontamination procedures. Real-time quaking-induced conversion [33,34], protein misfolding cyclic amplification [35-39], or transgenic mice overexpressing human PrP with the $129 \mathrm{~V}$ genotype [20] might be useful to detect the reduced infectivity of $\mathrm{Mi} \operatorname{PrP}^{\mathrm{Sc}}$ at high sensitivity. Using such sensitive detection systems, effective decontamination procedures for $\mathrm{Mi} \operatorname{PrP}^{\mathrm{Sc}}$ can be established in the future.

\section{Concluding remarks}

Recent progress in the study of the pathogenesis of $\mathrm{dCJD}$ has revealed that the two distinct subgroups of $\mathrm{dCJD}$ are caused by infection with different $\operatorname{PrP}^{\mathrm{Sc}}$ strains of sCJD, i.e., np-dCJD caused by $\mathrm{M} 1 \mathrm{PrP}^{\mathrm{Sc}}$ from sCJDMM1/MV1 and p-dCJD caused by Mi $\operatorname{PrP}^{\mathrm{Sc}}$ and/or V2 $\operatorname{PrP}^{\mathrm{Sc}}$ from sCJD-VV2, $-\mathrm{MV} 2 \mathrm{~K}$, or $-\mathrm{MV} 2 \mathrm{~K}+\mathrm{C}$. Studies have also revealed previously unrecognized problems such as the considerable risks of secondary infection from dCJD, particularly from $\mathrm{p}-\mathrm{dCJD}$. To prevent secondary infection from $\mathrm{p}-\mathrm{dCJD}$, the effectiveness of the current decontamination procedures should be tested urgently using sensitive Mi $\operatorname{PrP}^{\mathrm{Sc}}$ detection systems.

\section{Competing interest}

The authors declare that they have no competing interest.

\begin{abstract}
Acknowledgements
We thank members of the Creutzfeldt-Jakob Disease Surveillance Committee in Japan, Creutzfeldt-Jakob disease specialists in the prefectures, and Creutzeldt-Jakob disease patients and families for providing important clinical information. We thank Y. Ishikawa, H. Kudo, M. Yamamoto, and A. Yamazaki for their excellent technical assistance, and B. Bell for critical review of the manuscript. This study was supported by Grants-in-Aid from the Ministry of Health, Labor and Welfare of Japan (A.K., S.M., and T.K.), Grants-in-Aid for Scientific Research from the Ministry of Education, Culture, Sports, Science and Technology of Japan (A.K. and T.K.), and a grant for TSE research from the Ministry of Health, Labor and Welfare of Japan (H23-Shokuhin-Ippan-005) (T.K.).
\end{abstract}

\section{Author details}

'Department of Neurological Science, Tohoku University Graduate School of Medicine, 2-1 Seiryo-machi, Aoba-ku, Sendai 980-8575, Japan. ${ }^{2}$ Influenza and Prion Disease Research Center, National Institute of Animal Health, Tsukuba, Ibaraki 305-0856, Japan.

Received: 24 March 2014 Accepted: 24 March 2014

Published: 31 March 2014

\section{References}

1. Prusiner SB, Scott MR, DeArmond SJ, Cohen FE: Prion protein biology. Cell 1998, 93:337-348.

2. Brown P, Brandel JP, Sato T, Nakamura Y, MacKenzie J, Will RG, Ladogana A, Pocchiari M, Leschek EW, Schonberger LB: latrogenic Creutzfeldt-Jakob disease, final assessment. Emerg Infect Dis 2012, 18:901-907.
3. Hamaguchi T, Sakai K, Noguchi-Shinohara M, Nozaki I, Takumi I, Sanjo N, Sadakane A, Nakamura Y, Kitamoto T, Saito N, Mizusawa H, Yamada M: Insight into the frequent occurrence of dura mater graft-associated CreutzfeldtJakob disease in Japan. J Neurol Neurosurg Psychiatry 2013, 84:1171-1175.

4. Nakamura Y, Uehara R, Watanabe M, Sadakane A, Yamada M, Mizusawa H, Maddox R, Sejvar MPH J, Belay E, Schonberger L: Update: Creutzfeldt-Jakob disease associated with cadaveric dura mater grafts - Japan, 1978-2008. MMWR Morb Mortal Wkly Rep 2008, 57:1152-1154.

5. Nozaki I, Hamaguchi T, Sanjo N, Noguchi-Shinohara M, Sakai K, Nakamura Y, Sato T, Kitamoto T, Mizusawa H, Moriwaka F, Shiga Y, Kuroiwa Y, Nishizawa M, Kuzuhara S, Inuzuka T, Takeda M, Kuroda S, Abe K, Murai H, Murayama S, Tateishi J, Takumi I, Shirabe S, Harada M, Sadakane A, Yamada M: Prospective 10-year surveillance of human prion diseases in Japan. Brain 2010, 133:3043-3057.

6. Shimizu S, Hoshi K, Muramoto T, Homma M, Ironside JW, Kuzuhara S, Sato T, Yamamoto T, Kitamoto T: Creutzfeldt-Jakob disease with florid-type plaques after cadaveric dura mater grafting. Arch Neurol 1999, 56:357-362.

7. Hoshi K, Yoshino H, Urata J, Nakamura Y, Yanagawa H, Sato T: Creutzfeldt-Jakob disease associated with cadaveric dura mater grafts in Japan. Neurology 2000, 55:718-721.

8. Mochizuki Y, Mizutani T, Tajiri N, Oinuma T, Nemoto N, Kakimi S, Kitamoto T: Creutzfeldt-Jakob disease with florid plaques after cadaveric dura mater graft. Neuropathology 2003, 23:136-140.

9. Kretzschmar HA, Sethi S, Földvári Z, Windl O, Querner V, Zerr I, Poser S: latrogenic Creutzfeldt-Jakob disease with florid plaques. Brain Pathol 2003, 13:245-249.

10. Satoh K, Muramoto T, Tanaka T, Kitamoto N, Ironside JW, Nagashima K, Yamada M, Sato T, Mohri S, Kitamoto T: Association of an 11-12kDa protease-resistant prion protein fragment with subtypes of dura graft-associated Creutzfeldt-Jakob disease and other prion diseases. J Gen Virol 2003, 84:2885-2893.

11. Noguchi-Shinohara M, Hamaguchi T, Kitamoto T, Sato T, Nakamura $Y$, Mizusawa H, Yamada M: Clinical features and diagnosis of dura mater graft associated Creutzfeldt-Jakob disease. Neurology 2007, 69:360-367.

12. Yamada M, Noguchi-Shinohara M, Hamaguchi T, Nozaki I, Kitamoto T, Sato T, Nakamura Y, Mizusawa H: Dura mater graft-associated Creutzfeldt-Jakob disease in Japan: clinicopathological and molecular characterization of the two distinct subtypes. Neuropathology 2009, 29:609-618.

13. Lane KL, Brown P, Howell DN, Chain BJ, Hulette CM, Burger PC, DeArmond $\mathrm{SJ}$ : Creutzfeldt-Jakob disease in a pregnant woman with an implanted dura mater graft. Neurosurgery 1994, 34:737-740.

14. Kopp N, Streichenberger N, Deslys JP, Laplanche JL, Chazot G: Creutzfeldt-Jakob disease in a 52-year-old woman with florid plaques. Lancet 1996, 348:1239-1240.

15. Takashima S, Tateishi J, Taguchi Y, Inoue H: Creutzfeldt-Jakob disease with florid plaques after cadaveric dural graft in a Japanese woman. Lancet 1997, 350:865-866.

16. Kimura K, Nonaka A, Tashiro H, Yaginuma M, Shimokawa R, Okeda R, Yamada M: Atypical form of dura graft associated Creutzfeldt-Jakob disease: report of a postmortem case with review of the literature. J Neurol Neurosurg Psychiatry 2001, 70:696-699.

17. Parchi P, Giese A, Capellari S, Brown P, Schulz-Schaeffer W, Windl O, Zerr I, Budka H, Kopp N, Piccardo P, Poser S, Rojiani A, Streichemberger N, Julien J, Vital C, Ghetti B, Gambetti P, Kretzschmar H: Classification of sporadic Creutzfeldt-Jakob disease based on molecular and phenotypic analysis of 300 subjects. Ann Neurol 1999, 46:224-233.

18. Parchi P, Strammiello R, Giese A, Kretzschmar H: Phenotypic variability of sporadic human prion disease and its molecular basis: past, present, and future. Acta Neuropathol 2011, 121:91-112.

19. Parchi P, Zou W, Wang W, Brown P, Capellari S, Ghetti B, Kopp N, Schulz-Schaeffer WJ, Kretzschmar HA, Head MW, Ironside JW, Gambetti P, Chen SG: Genetic influence on the structural variations of the abnormal prion protein. Proc Natl Acad Sci USA 2000, 97:10168-10172.

20. Kobayashi A, Asano M, Mohri S, Kitamoto T: Cross-sequence transmission of sporadic Creutzfeldt-Jakob disease creates a new prion strain. J Biol Chem 2007, 282:30022-30028.

21. Parchi $P$, Strammiello R, Notari S, Giese A, Langeveld JP, Ladogana A Zerr I, Roncaroli F, Cras P, Ghetti B, Pocchiari M, Kretzschmar H, Capellari S: Incidence and spectrum of sporadic Creutzfeldt-Jakob disease variants with mixed phenotype and co-occurrence of PrP ${ }^{\mathrm{Sc}}$ types: an updated classification. Acta Neuropathol 2009, 118:659-671. 
22. Kobayashi A, Asano M, Mohri S, Kitamoto T: A traceback phenomenon can reveal the origin of prion infection. Neuropathology 2009, 29:619-624.

23. Kobayashi A, Iwasaki Y, Otsuka H, Yamada M, Yoshida M, Matsuura Y, Mohri S, Kitamoto T: Deciphering the pathogenesis of sporadic Creutzfeldt-Jakob disease with codon 129M/ $\mathrm{V}$ and type 2 abnormal prion protein. Acta Neuropathol Commun 2013, 1:74.

24. Bishop MT, Will RG, Manson JC: Defining sporadic Creutzfeldt-Jakob disease strains and their transmission properties. Proc Natl Acad Sci USA 2010, 107:12005-12010.

25. Kobayashi A, Sakuma N, Matsuura Y, Mohri S, Aguzzi A, Kitamoto T: Experimental verification of a traceback phenomenon in prion infection. J Virol 2010, 84:3230-3238.

26. Asano M, Mohri S, Ironside JW, Ito M, Tamaoki N, Kitamoto T: vCJD prion acquires altered virulence through trans-species infection. Biochem Biophys Res Commun 2006, 342:293-299.

27. Taylor DM, Fraser H, McConnell I, Brown DA, Brown KL, Lamza KA, Smith GR: Decontamination studies with the agents of bovine spongiform encephalopathy and scrapie. Arch Virol 1994, 139:313-326.

28. Rutala WA, Weber DJ: Creutzfeldt-Jakob disease: recommendations for disinfection and sterilization. Clin Infect Dis 2001, 32:1348-1356.

29. Rogez-Kreuz C, Yousfi R, Soufflet C, Quadrio I, Yan ZX, Huyot V, Aubenque C, Destrez P, Roth K, Roberts C, Favero M, Clayette P: Inactivation of animal and human prions by hydrogen peroxide gas plasma sterilization. Infect Control Hosp Epidemiol 2009, 30:769-777.

30. Brown P, Gibbs CJ Jr, Amyx HL, Kingsbury DT, Rohwer RG, Sulima MP, Gajdusek DC: Chemical disinfection of Creutzfeldt-Jakob disease virus. N Engl J Med 1982, 306:1279-1282.

31. Taguchi F, Tamai Y, Uchida K, Kitajima R, Kojima H, Kawaquchi T, Ohtani Y, Miura S: Proposal for a procedure for complete inactivation of the Creutzfeldt-Jakob disease agent. Arch Virol 1991, 119:297-301.

32. Tateishi J, Tashima T, Kitamoto T: Practical methods for chemical inactivation of Creutzfeldt-Jakob disease pathogen. Microbiol Immunol 1991, 35:163-166.

33. Wilham JM, Orrú CD, Bessen RA, Atarashi R, Sano K, Race B, Meade-White KD, Taubner LM, Timmes A, Caughey B: Rapid end-point quantitation of prion seeding activity with sensitivity comparable to bioassays. PLoS Pathog 2010, 6:e1001217.

34. Atarashi R, Satoh K, Sano K, Fuse T, Yamaguchi N, Ishibashi D, Matsubara T, Nakagaki T, Yamanaka H, Shirabe S, Yamada M, Mizusawa H, Kitamoto T, Klug G, McGlade A, Collins SJ, Nishida N: Ultrasensitive human prion detection in cerebrospinal fluid by real-time quaking-induced conversion. Nat Med 2011, 17:175-178.

35. Saborio GP, Permanne B, Soto C: Sensitive detection of pathological prion protein by cyclic amplification of protein misfolding. Nature 2001, 411:810-813.

36. Suyama K, Yoshioka M, Akagawa M, Murayama Y, Horii H, Takata M, Yokoyama T, Mohri S: Assessment of prion inactivation by fenton reaction using protein misfolding cyclic amplification and bioassay. Biosci Biotechnol Biochem 2007, 71:2069-2071.

37. Yoshioka M, Murayama Y, Miwa T, Miura K, Takata M, Yokoyama T, Nishizawa K, Mohri S: Assessment of prion inactivation by combined use of Bacillus-derived protease and SDS. Biosci Biotechnol Biochem 2007. 71:2565-2568.

38. Beekes M, Lemmer K, Thomzig A, Joncic M, Tintelnot K, Mielke M: Fast, broad-range disinfection of bacteria, fungi, viruses and prions. J Gen Virol 2010, 91:580-589.

39. Takeuchi A, Komiya M, Kitamoto T, Morita M: Deduction of the evaluation limit and termination timing of multi-round protein misfolding cyclic amplification from a titration curve. Microbiol Immunol 2011, 55:502-509.

doi:10.1186/2051-5960-2-32

Cite this article as: Kobayashi et al:: Distinct origins of dura mater graft-associated Creutzfeldt-Jakob disease: past and future problems. Acta Neuropathologica Communications 2014 2:32.

\section{Submit your next manuscript to BioMed Central and take full advantage of:}

- Convenient online submission

- Thorough peer review

- No space constraints or color figure charges

- Immediate publication on acceptance

- Inclusion in PubMed, CAS, Scopus and Google Scholar

- Research which is freely available for redistribution

Submit your manuscript at www.biomedcentral.com/submit
C Biomed Central 